\title{
The Role of Supporting Institutions and the Problems of Vegetable Agribusiness Development in Aceh
}

\author{
Suyanti Kasimin \\ Agribusiness Master's Program, Faculty of Agriculture, Syiah Kuala University \\ $\left\{{ }^{1}\right.$ suyantikasimin@yahoo.com $\}$
}

\begin{abstract}
This study was carried out to analyze the characteristics of vegetable farmers in Aceh on the condition of the supporting institutions they have and their influence on the development of vegetable agribusiness in Aceh. The method of analysis used is T-test between characteristics of supporting institutions and the level of productivity and income level of vegetable farming in Aceh. Through analysis towards farming of 50 farmers in 2 regencies of vegetable production centers in Aceh, the results showed that although the characteristics of supporting institutions in the development of vegetable agribusiness in Aceh were relatively poor, these characteristics significantly affected the level of productivity and income levels of vegetable farmers in Aceh. For this reason, it is necessary to improve the characteristics of supporting institutions in Aceh so that vegetable agribusiness develops well.
\end{abstract}

Keywords: Characteristics of Supporting Institutions, Vegetable Farmers, Agribusiness Development

\section{Introduction}

Supporting institutions may be in the form of government apparatus or advisory institutions, financing institutions, distribution and transportation institutions, research and education institutions, communication and information institutions. These institutions are crucial in the effort to create agribusiness integration to achieve agribusiness development goals. The existence of these supporting institutions is very important to create a strong and competitive agribusiness because it is an integral part of the agribusiness system [1].

Agribusiness development is a development which is an integral part with the development of related industries and services in a development area that includes five subsystems from upstream to downstream simultaneously and harmoniously [2], [3]. Besides achieving economic development, agribusiness development also has an impact on overall regional development, through increasing inter-regional dependence and developing competitive and comparative advantages of agricultural products.

Supanggih \& Widodo (2013) stated that capital constraints, interest rate fluctuations, and lack of credit information are major problems faced by many farmers. Credit is needed by the farmers to increase production, product quality and increase investment to increase profits. Meanwhile, Isaac (2012) stated that credit would be given if the farming was profitable, feasible to cultivate, and low risk. Furthermore, credit is needed for investment capital, business development, and working capital. 
Characteristics of supporting institutions that weak in the development of rural agribusiness require prioritizing on moral ethics and sustainable development goals to ensure the success of rural agribusiness [6].

Infrastructure policies, especially transportation and irrigation facilities, are a number of intensive government efforts in several regions. It is realized that these two infrastructures will quickly increase crop productivity and open up the isolation of the region so that the flow of goods and information can run without significant obstacle (Soekartawi, 1993:33). The availability of roads that are not supported by the infrastructure of the social environment (security) and the physical economic environment (high demand for a commodity) resulting comparative advantage that cannot be utilized optimally. For this reason, it is necessary to examine the farmers' access to supporting institutions and their influence on the level of production and income.

\section{Method}

\subsection{Location, Object, and Scope}

The study was conducted in Central Aceh and Bener Meriah; regencies of vegetable production centers in Aceh. The object of research is the vegetable farming development unit including farmers, factors that influence the performance of supporting the institution, including the number of sources of working capital, guidance, and counseling, road and transportation conditions, as well as communication and information facilities.

\subsection{Population and Sampling Method}

The research's population is the population which is become the scope of the research's conclusion [8]. Vegetable farmers, intermediary traders, supporting service providers, and agricultural extension agents are the target population.

Sampling is done by Multistage Random Sampling technique; a sampling technique which based on the population area and samples randomly stratified at the specified research location. Assuming the homogeneous farmer characteristics [9], and then each regency was sampled with the same amount of 50 farmers from 2 selected sub-districts, and each subdistrict was taken by 25 farmers from 2 selected villages. The number of sub-districts in this study was 4 sub-districts and 8 villages.

\subsection{Analysis Method}

To measure the effect of farmers' access to supporting institutions, T-tests are conducted between access to supporting institutions against income levels, and access to supporting institutions against vegetable productivity. It will be seen the inclination that exists between access to the services of supporting institutions and the level of income and productivity. Furthermore, a T-test will be conducted to distinguish the level of accessibility with the level of income and productivity owned by farmers. Access to supporting institutions is measured by farmers' accessibilities: a number of working capital institutions (X1); road and transportation conditions (X2); communication and information facilities (X3); coaching institution (X4).

Formulation of hypotheses is arranged as follows: 
$\mathrm{H}_{\mathrm{o}} \quad=$ there are no differences in the level of production and income of farmers based on farmers' access to supporting institutions.

$\mathrm{H}_{\mathrm{a}} \quad=$ there are differences in the level of production and income of farmers based on farmers' access to supporting institutions.

The criteria of decision making are as follows: null hypothesis $\left(\mathrm{H}_{0}\right)$ is accepted if price $\mathrm{F}_{\text {count }}$ smaller or equal with $\mathrm{F}_{\text {table }}\left(\mathrm{F}_{\text {count }}<\mathrm{F}_{\text {table }}\right)$, and is rejected if $\mathrm{F}_{\text {count }}$ bigger than $\mathrm{F}_{\text {table }}\left(\mathrm{F}_{\text {count }}>\mathrm{F}_{\text {table }}\right)$.

\section{Results And Discussions}

\subsection{Characteristics of Vegetable Farmer Supporting Institutions in Aceh}

Table 1 below shows the characteristics of supporting institutions in the development of vegetable farming in Aceh. The access of vegetable farmers in Aceh to supporting institutions is very low. This can be seen from the relatively low amount of available working capital and a source of capital that is mostly sourced from their own capital $(48.9 \%)$. This will make it difficult for farmers to develop their farms. The amount of capital resources that can be utilized by farmers is relatively low. On average, there are only 2 sources: their own capital or loan capital from another source, such as neighbors, middlemen, and the government. The role of the government in providing working capital is only 9.8 percent, therefore this must be increased again.

It can be seen from the table that farmers are experiencing capital limitations for further farming development. This can be seen from the total costs incurred in planting vegetables is Rp. 18,742,706.00/hectare with a planting area of 0.542 ha, therefore the amount of capital needed is Rp. 10,158,547, while the amount of available costs is Rp. 8,826,989, hence it can be said that farmers still need working capital as much as Rp. 1,331,558 (13.1\%) or Rp. 9,915,717.00 / hectare (52.9\%).

Table 1: Characteristics of Vegetable Farmer Supporting Institutions in Aceh

\begin{tabular}{|c|c|c|c|c|c|c|c|}
\hline \multirow[b]{2}{*}{ Supporting institutions } & \multicolumn{2}{|c|}{ Central Aceh Regency } & \multirow{2}{*}{$\begin{array}{c}\text { Central } \\
\text { Aceh } \\
\text { Regency } \\
\text { Averages }\end{array}$} & \multicolumn{2}{|c|}{ Bener Meriah Regency } & \multirow{2}{*}{$\begin{array}{c}\text { Bener } \\
\text { Meriah } \\
\text { Regency } \\
\text { Averages }\end{array}$} & \multirow{2}{*}{ Aceh } \\
\hline & $\begin{array}{c}\text { Jagong } \\
\text { Jeget } \\
\text { Sub-district }\end{array}$ & $\begin{array}{c}\text { Pegasing } \\
\text { Sub-district }\end{array}$ & & $\begin{array}{c}\text { Bukit } \\
\text { Sub-district }\end{array}$ & $\begin{array}{c}\text { Permata } \\
\text { Sub-district }\end{array}$ & & \\
\hline $\begin{array}{l}\text { 1. Working Capital (X1) } \\
\text { a. Capital Source }\end{array}$ & & & & & & & \\
\hline - Owner $(\%)$ & 59,1 & 58,8 & 58,9 & 29,2 & 48,4 & 38,8 & 48,9 \\
\hline - Neoghbour (\%) & 22,0 & 28,6 & 25,3 & 14,4 & 16,3 & 15,4 & 20,4 \\
\hline - Middlemen/Wholesaler (\%) & 6,9 & 12,1 & 9,5 & 54,8 & 8,7 & 31,8 & 20,7 \\
\hline - Goverment $(\%)$ & 12,0 & 0,5 & 6,3 & 0 & 26,6 & 13,3 & 9,8 \\
\hline b. Total Capital (Rp/planting) & 3958333 & 5794000 & 5594917 & 19540000 & 4578000 & 12059000 & 8826989 \\
\hline c. Total Source: & 2,04 & 1,84 & 1,9 & 3,28 & 2,4 & 2,8 & 2,4 \\
\hline 2. Distance to market (KM) & 39,8 & 23,4 & 31,6 & 0,92 & 12,84 & 6,9 & 19,3 \\
\hline $\begin{array}{l}\text { 3. Transportation (X2) } \\
\text { - Farm to market } \\
\text { - Road condition }\end{array}$ & $\begin{array}{l}1,9 \\
1,9\end{array}$ & $\begin{array}{l}1,6 \\
2,5\end{array}$ & $\begin{array}{l}1,8 \\
2,2\end{array}$ & $\begin{array}{l}2,7 \\
3,0\end{array}$ & $\begin{array}{l}1,8 \\
2,2\end{array}$ & $\begin{array}{l}2,3 \\
2,6\end{array}$ & $\begin{array}{l}2,1 \\
2,4\end{array}$ \\
\hline 4. Source of information (X3) & & & & & & & \\
\hline
\end{tabular}




\begin{tabular}{|c|c|c|c|c|c|c|c|}
\hline a. vegetable price information & & & & & & & \\
\hline - Farmers $(\%)$ & 12,0 & 12,0 & 12,0 & 0,0 & 4,0 & 2,0 & 7,0 \\
\hline - Merchant (\%) & 68,0 & 80,0 & 74,0 & 100,0 & 92,0 & 96,0 & 85,0 \\
\hline $\begin{array}{l}\text { - PPL, radio, newspaper }(\%) \\
\text { b.Technical Information }\end{array}$ & 20,0 & 8,0 & 14,0 & 0,0 & 4,0 & 2,0 & 8,0 \\
\hline - Family (\%) & 12,0 & 36,0 & 24,0 & 20,0 & 32,0 & 26,0 & 25,0 \\
\hline - Farmer/neighbour (\%) & 28,0 & 48,0 & 38,0 & 48,0 & 44,0 & 46,0 & 42,0 \\
\hline - PPL, radio, newspaper (\%) & 60,0 & 16,0 & 38,0 & 32,0 & 24,0 & 28,0 & 33,0 \\
\hline 5. Coaching Amount (X4)) & 0,8 & 0,4 & 0,6 & 1,0 & 2,3 & 1,7 & 1,2 \\
\hline 6. Communication facilities & 1,9 & 1,2 & 1,6 & 3,2 & 1,8 & 2,5 & 2,1 \\
\hline
\end{tabular}
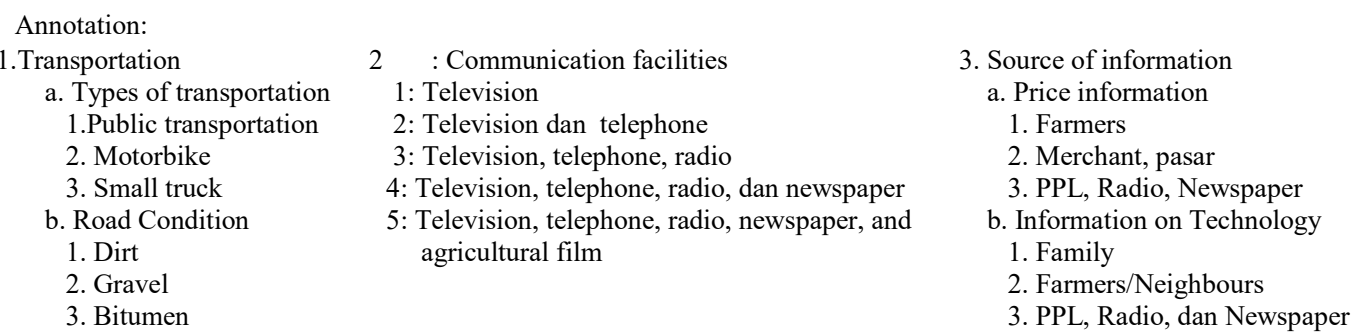

The distance from the farm to the market is relatively far at $19.3 \mathrm{~km}$, with a motorcycle as transportation to the farm. Road conditions to the farm are dirt and hilly, making it difficult for farmers to bring crops, especially during rainy weather.

The amount of coaching is almost never officially available (1.2 times/year), if there is a technical difficulty, the farmer will ask other farmers (42\%), and only $33 \%$ to the PPL, radio or newspaper, while the issue of price information $85 \%$ of farmers entrusted them to intermediary traders (middlemen/wholesaler), and only $7 \%$ of farmers mastered price information, the remaining, PPL, radio and newspapers are $8 \%$. The high price information from merchants shows that the selling price of vegetables is controlled by traders, and farmers only as price takers.

Here there is an asymmetric flow of price information that causes price information to be hampered that should benefit farmers. Because only as a recipient of prices, the price fluctuations that occur tend to disadvantage farmers, this can be seen from farmers' difficulty to get good income when the selling price of vegetables is high, and the difficulty of farmers avoiding losses when the price of vegetables is low.

In Bukit sub-district, vegetables are very potential to be developed, and a very large role must be and can be done by regency and provincial governments. This is a sub-district that has the closest distance between the farm and the market, but they buy seeds and sell the product not to the nearest market $(1 \mathrm{~km})$, but to markets outside Aceh, but to North Sumatra Province which is over $400 \mathrm{~km}$. Thus farmers' access to the nearest market operationally in vegetable farming in this sub-district cannot be optimized, because the inability (failure) of the market provides the things needed by vegetable farmers, so even though the level of productivity is high, cheap labor costs, fertile land, and experience farmers are good enough, but because

of market failures to provide inputs and absorption of output, the costs of production and marketing output are high, and income levels are low. For this reason, the role of the government is needed to improve the function of the Bukit market. 
Generally, communication facilities owned by farmers are television, which cannot directly solve the problems faced by farmers, and only a small percentage of farmers have cellphones and radios $(1-2 \%)$.

\subsection{The effect of Condition of Supporting Institutions on Vegetable Agribusiness Development in Aceh.}

Farmers' access to supporting institutions services is measured by: (1) the number of working capital institutions, (2) the amount of coaching, (3) road conditions, and (4) communication and information facilities owned by farmers. It will be seen whether there is a link between farmers' access to the services of supporting institutions and the level of production and the level of income of farmers. The relationship of farmers' access to supporting institutions with the level of production and the level of income of farmers is shown in Table 2.

Table 2. Probability of F Value towards Productivity and Income of Vegetable Farming in Aceh, 2017

\begin{tabular}{|l|l|l|}
\hline Types of Supporting Institutions & $\begin{array}{l}\text { Probability F } \\
\text { towards } \\
\text { Productivity }\end{array}$ & $\begin{array}{l}\text { Probability F } \\
\text { towards Income }\end{array}$ \\
\hline 1. Number of Communication and Information Facilities & $0,000^{* * *}$ & $0,000^{* * *}$ \\
2. Number of Coaching Participants & $0,008^{* *}$ & $0,000^{* * *}$ \\
3. Village Road Conditions & $0,000^{* * *}$ & $0,000^{* * *}$ \\
4. Number of Working Capital Institutions & $0,004 * *$ & $0,000^{* * *}$ \\
\hline
\end{tabular}

** : Significantly different, with $\alpha=0,10$

$* * *$ : Significantly different, with $\alpha=0,05$

Supporting institution services are significantly related to the increase in income of vegetable farmers in Aceh. This can be seen from the significance value of the influence of supporting institutions services on income levels. The services of supporting institutions to production levels are significantly influenced by the number of coaching participants and the number of communication and information facilities. This shows that a good coaching pattern and increased access to information mastery will increase the production and income of vegetable farmers in Aceh.

Based on Table 2, it can be seen that all four sizes of supporting institutions owned by farmers will relate significantly to the level of production and income level of vegetable farming in Aceh. This is consistent with the statement of Gumbira [10], which stated that supporting institutions are very important to create agribusiness integration in achieving agribusiness development goals.

The actual condition shows that farmers experience capital limitation and lack of credit information, and this is a significant problem faced by many farmers. Ricketts \& Rawlins [11] say that credit is needed to increase production, product quality and increase investment to increase income. Credit will be given if the farm is profitable, feasible to cultivate, and low risk. Furthermore, Saragih [12] stated that credit is needed for investment capital, business development, and working capital.

The same result is obtained by Nakagawa [13] who stated that the limitations of cash and working capital have limited the ability of farmers to buy high-quality seeds and encourage farmers to borrow money from various informal financial sources such as Bandar (middlemen), 
input suppliers, friends or neighbors with small guarantees and high-interest rates. This condition has hampered the development of vegetable production and productivity in Southeast Asia in general and Indonesia in particular (including in Aceh).

The difficulty experienced by the farmers in providing intensive working capital in vegetable cultivation and other vegetable cultivation occurs not only in Aceh but also in cabbage farming in Solok, West Sumatra with 55\% used their own capital [14], and on non-contracted vegetable farming in Java-West with 85.9\% used own capital [15]. The limitations of farmers in providing capital and obtaining credit by Jigang [16] and Karmana [17] are referred to as structural and cultural weaknesses of farmers so that they have difficulties developing their farms.

A less harmonious relationship between some farmers and coaches arises because of differences in interests, where the coaches, in addition to giving training, they also participate in planting and selling vegetable farming products, and seeking program funds as a pilot project. When the pilot project funds come out, farmers are not involved again. This caused displeasure feeling and caused the farmers' trust in the coach to be reduced. This condition also caused confusion for some farmers. Coaching is needed because farmers need to get information on technology that continues to grow [18]. In addition, agricultural extension tasks should not only provide information on technology, but also information about market prices and the tendency to increase value added from processing vegetables that are in high demand.

The road assessed is the village road to the district market. Road conditions are said to be adequate if the road conditions are paved, inadequate if the road from the village to the district market is gravely, and inadequate if the road is mixed with dirt, holes and muddy. Prayogo said that to improve the competitiveness of agricultural commodities facing free markets, the first thing to do is: farmers' access to supporting institutions, such as the construction and rehabilitation of infrastructure such as roads, and transportation facilities used.

There are 5 types of communication and information facilities that are measured: television, cellphones/mobile phones, agricultural films, radio, and newspapers. Generally, farmers have a television, few farmers use cellphones and rarely do farmers have agricultural film, radio and newspaper communication facilities. Farmer communication facilities are considered to be very complete if they have the 5 types of communication facilities and information above. Considered complete enough they have 3-4 communication facilities and information above; considered incomplete, if they only have 2 and 1 of the communication facilities above.

Infrastructure-related policies, especially transportation and irrigation facilities, are a number of intensive government efforts carried out in several regions. It is realized that these two infrastructures will quickly increase crop productivity and open up regional isolation so that the flow of goods and information can run flawlessly [10], [19].

Simatupang [20] stated that communication facilities that are not functioning properly will cause transmission of asymmetrical prices, restrained market information, and consumer preferences, transmitted technological developments, and not the good distribution of investment capital downstream to upstream agribusiness.

Based on the description above, it can be seen that all the supporting institution service factors are significantly related to the level of production and income of vegetable farmers in Aceh. This means that the better the conditions of supporting institutions owned by farmers, the higher the chances of achieving increased crop productivity and the income of vegetable farmers in Aceh. Thus it can be concluded that one way to increase the production and income of vegetable farmers in Aceh is through improving the conditions of supporting institutions owned by farmers.

Direktorat Jenderal Hortikultura, Kementerian Pertanian (2015)[21] identified several causes of low vegetable productivity in Indonesia: (a) lack of business institutional support and 
marketing, (b) low on product competitiveness, (c) unfinished and equitable market structure, (d ) the market information system is not quick, precise and effective, and (e) the low adoption of cultivation technology.

This is consistent with the statement of Soehardjo [2], as a system, the development of agribusiness requires certainty of the proper functioning of each subsystem and mutual movement between subsystems [10], [19].

If the linkages between subsystems are low, then the goals of agribusiness development to increase the income of farmers and other actors and guarantee the availability of food for the community will not be achieved. So that the hypothesis testing states that: The level of production and income of vegetable farmers associated with the services of supporting institutions owned by farmers, considered to be proven.

\subsection{Problems in Vegetable Agribusiness Development in Aceh}

Kasimin [3] stated that the problems faced by farmers in horticultural agribusiness development in Aceh are generally in the production subsystem and marketing subsystem caused by lack of production facilities and lack of support from supporting institutions. The conditions that arise will result in the interconnection between subsystems to become low and disconnected. This can be seen from the lack of working capital, the high attack of pests and diseases, and the unavailability of production facilities (seeds, fertilizers, and pesticides) at farmers. This is due to the high business capital for planting horticulture, while the ability of farmers to provide working capital is only $50 \%$, while the rest of the farmers seek loans from middlemen, neighbors, relatives, and the government.

\section{Conclusions}

1. Characteristics of vegetable farmers supporting institutions in Aceh significantly affect the development of vegetable agribusiness in Aceh. With these unfavorable characters, the improvement of the characteristics of supporting institutions will accelerate the development of vegetable agribusiness in Aceh.

2. Improvement on the characteristics of vegetable farmers supporting institutions can be carried out through increasing the role of the government in providing working capital for farmers, enhancing market functions, increasing coaching and strengthening market information.

3. The problem of vegetable agribusiness development besides being influenced by supporting institutions is also influenced by the availability of production facilities.

\section{REFERENCES}

[1] W. D. Downey and S. P. Erickson, Manajemen agribisnis (Terjemahan R. Ghanda S. dan A. Sirait), 2nd ed. Jakarta: Erlangga, 1992.

[2] A. Soehardjo, "Sistem agribisnis dan agroindustri," Bogor, 1997.

[3] S. Kasimin, "Keterkaitan produk dan pelaku dalam pengembangan agribisnis hortikultura unggulan di propinsi Aceh," J. Manaj. Agribisnis, vol. 10, no. 2, pp. 117127, 2013.

[4] D. Supanggih and S. Widodo, "Aksesibitas petani terhadap lembaga keuangan (Studi kasus pada petani di desa Sidodadi kecamatan Sukosewu kabupaten Bojonegoro)," J. Agriekonomika, vol. 2, no. 2, pp. 163-173, 2013.

[5] M. E. Isaac, "Agricultural information exchange and organizational ties: the effect of 
network topology on managing agrodiversity," Agric. Syst., vol. 109, pp. 9-15, 2012.

[6] S. Wahyuningsih, "Pengembangan agribisnis di tinjau dari kelembagaan," Mediagro, vol. 3, no. 1, pp. 9-20, 2007.

[7] Soekartawi, Agribisnis teori dan aplikasinya. Jakarta: Raja Garfindo Persada, 1993.

[8] H. Herdiansyah, Metode penelitian kualitatif untuk ilmu-ilmu sosial. Jakarta: Salemba Humanika, 2011.

[9] W. Idha, A. Arsanti, M. Böhme, and H. E Jahnke, "Resource use efficiency and competitiveness of vegetable farming systems in upland areas of Indonesia," in International Agricultural Research for Developmen, 2007.

[10] E. S. Gumbira, "Kondisi dan permasalahan agribisnis Indonesia," Buletin Kawasan, 2002.

[11] C. Ricketts and O. Rawlins, Introduction to agribusiness. Singapore: Delmar Publishers, 2001.

[12] J. R. Saragih, "Strategi pengembangan agribisnis hortikultura di wilayah pedesaan," in Prosiding Seminar Ilmiah Nasional Dies Natalis USU 64, 2016.

[13] Nakagawa, Agribusiness seed potato sector. Bandung: JBIC \& JICA, 2005.

[14] B. Rahmanto, "Studi agribisnis kubis di Sumatera Barat," Bogor, 2004.

[15] L. Sulistyowati, "Usahatani kontrak (contract farming) pada agribisnis sayuran serta peranannya dalam optimasi penggunaan faktor produksi (Kasus petani sayuran dataran tinggi di Jawa Barat) Disertas.," Universitas Padjadjaran, 2003.

[16] L. Jigang, "Influence of rural financial resources on farmer's income in China's underdeveloped areas," China, 2007.

[17] M. H. Karmana, "Peranan organisasi petani dalam menunjang revitalisasi pertanian," in Simposium Model Implementasi Kebijakan Revitalisasi Pertanian, Perikanan dan Kehutanan dalam Rangka Dies Natalis ke 48 Universitas Padjadjaran, 2005.

[18] W. Adiyoga, T. Soetiarso, M. Ameriana, and W. Setiawati, "Pengkajian ex ante manfaat potensial adopsi varietas unggul bawang merah di Indonesia," J. Hortik., vol. 19, no. 3, pp. 356-370, 2009.

[19] H. Siregar and Nely, "Membangun sistem ketahanan pangan dan agribisnis yang tangguh dan sustainable melalui RPPK," Semarang, 2005.

[20] P. Simatupang, "Industrialisasi pertanian sebagai strategi agribisnis dan pembangunan pertanian dalam era globalisasi," Bogor, 2003.

[21] Direktorat Jenderal Hortikultura, Kementerian Pertanian, Statistik produksi holtikultura tahun 2014. Jakarta: Direktorat Jenderal Hortikultura, Kementerian Pertanian, 2015. 